\title{
Expression of Personalization while Developing Long-Term Relationships with Service Customers
}

\author{
Jurate Banyte, Agne Gadeikiene, Ausra Rutelione, Inga Kakneviciene
}

Kaunas University of Technology

Gedimino st. 50, 44239, Kaunas, Lithuania

E-mail.jurate.banyte@ktu.lt,agne.gadeikiene@ktu.lt,ausra.rutelione@ktu.lt,inga.kakneviciene@gmail.com

cross $^{\text {ref }} \underline{\text { http://dx.doi.org/10.5755/j01.ee.27.4.14159 }}$

\begin{abstract}
Efforts directed towards customer retention highly depend on the area in which company operates. Personalization is considered as one of the most effective means for service companies to develop long-term relationships with their customers. However, it still remains unclear how personalization should be expressed while developing long-term relationships with service customers. Thus, the aim of this study is to reason theoretically the effect of personalization on long-term relationships with service customers and to test it empirically on the example of high personal contact services. Theoretical studies reveal that personalized interaction between a service customer and a company is a three-dimensional construct, dimensions of which are personalized contact, personalized physical environment, and customer environment. Results of personalization in the context of the long-term relationships development are expressed through relationship quality (trust, satisfaction, and commitment) and customer loyalty (loyalty to a service company and loyalty to a certain employee). Hair salon services were chosen as a case for the empirical research. Results of the empirical research show that dimensions of personalized interaction influence both relationship quality dimensions and relationship results. The most significant dimension of personalized interaction while developing long-term relationships with customers of hair salons is personalized contact. The paper gives some practical insights for the development of long-term relationships with customers of hair salons.
\end{abstract}

Keywords: High-Contact Services, Personalization, Personalized Interaction, Relationship Quality, Loyalty.

\section{Introduction}

Intensive competition, lower barriers to entering markets, growing uncertainties among limits of different markets, market fragmentation and shorter product life cycles oblige companies to search for new ways to gain competitive advantage, at the same time giving increased attention towards retention of customers. Thus, the main strategic objectives in companies require searching for uniqueness and satisfaction of customer expectations (Hanzah, Othman \& Hassan, 2016; Rod, Ashill \& Gibbs, 2016). In such circumstances, personalized offers, which deliver value both for the customer and the company, become of the highest relevancy.

Creation of personalized offer, which satisfies customer needs, requires companies to focus on the implementation of dynamic personalization process and getting feedback from all participants in it. This is confirmed by insights of different researchers (Pierrakos, Paliouras, Papatheodorou \& Spyropoulos, 2003; Adomavicius \& Tuzhilin, 2005; Vesanen, 2007; Kwon \& Kim, 2012; Wang \& Kobsa, 2013) stating that in case of modern companies, which seek economic, social and emotional value not only for themselves but also for customers, it is important to develop long-term relationships with customers. Moreover, Shen \& Ball (2009) consider expression of personalization while developing long-term relationships with customers as a prerequisite for gaining competitive advantage in modern service companies. In this context works of Udorn, Bloom \& Zeihaml (1998), Shamdasani \& Balakrishnan (2000), Hennig-Thurau, Gwinner, \& Gremler (2002), Ball, Coelho \& Vilares (2006), Wall \& Berry (2007), Shen \& Ball (2009) should also be mentioned, as they research relations between personalization, antecedents and results of long-term relationships with customers.

Considering insufficient revelation of the mentioned phenomenon and discursive aspects in the field, this paper solves the scientific problem of how personalized offers affect long-term relationships with service customers, i.e. what the dimensions of personalized interaction between a customer and a service company are and how they affect results of the relationships with customers. This paper contributes to the existing knowledge by integration of the assumptions of different researchers in the field and by providing the holistic picture of personalized interaction and its impact on relationship quality and relationship results. Since different studies are oriented toward analysis of the particular dimensions of relationship quality, this paper integrates all of them, i.e. satisfaction, trust and commitment. In addition, loyalty is considered as the two-dimensional construct, which is composed of loyalty to the company and loyalty to a certain employee.

Research aim - to reason theoretically the effect of personalization on long-term relationships with service customers and to test it empirically on the example of high personal contact services.

Research methods: when performing theoretical studies, the methods of comparative analysis and systematization of scientific literature were applied. The quantitative method of data gathering (questionnaire survey) was applied in the empirical research. For the data analysis, methods of descriptive statistics, factor and regression analysis were applied. 


\section{Theoretical Background}

Personalization. Personalization as a concept is not new in marketing. Researchers discussed it since the 1870 s (Vesanen \& Raulas, 2006), and analyses on relations between personalization and segmentation, and the selection of target markets started in 1970s (Petrison, Blattberg \& Wang, 1997). In its early development stage, personalization had quite a narrow meaning: personal appeal to customers, interest in personal customer needs, etc. Later, in the beginning of the $21^{\text {st }}$ century, fast development of information and communication technologies (ICT) allowed to gather, store and analyse customer data more easily. These circumstances increased the possibilities to provide more personalized value propositions to customers as well as develop closer relationships with them. More and more scientists acknowledge that standardized products and services have limitations in terms of satisfying customer needs and increasing customer loyalty (Rod et al., 2016). Kwon \& Kim (2012) argue, "personalization is a strategic tool for product or service differentiation, especially when competition is keen in the market".

Studies on personalization demonstrate certain differences in its interpretation. Vesanen (2007) argues that personalization is the analysis and application of data, which is gathered using ICT and is intended to create closer relations between the company and the customer. Such approach reveals the importance of ICT while interpreting personalization. Imhoff, Loftis \& Geiger (2001), Piccoli, Lui \& Grün (2017) emphasize that personalization gives opportunity for companies to know and understand better present and potential customers. Simonson (2005) states that personalization allows creating long-term relationships with customers. The author considers interactions between customers and service providers as an expression of personalization.

Other authors analyse personalization as a process. Blom \& Monk (2007) state that during personalization process, unique company's characteristics are created and long-term relationships with customers are being developed. Decisions related to personalization process should be oriented to satisfaction of customer needs, customer value creation, cost optimization and maintenance of relationships with customers (Fiore, Lee \& Kunz, 2004). Ho (2006) adds that in the context of continual ICT development personalization becomes quite easy to control.

Analysis of personalization as a process is reasoned by its main result - combination of value to a customer and value to a company (Vesanen, 2007). In both cases, value is revealed as a ratio between benefits and costs (Rajaguru, 2016). Value to a customer is considered to be a prerequisite for the creation of value for a company (Smith \& Colgate, 2007). Personalized proposition (decisions related to marketing mix) is created during interaction between the company and the customer and is monitored not only during the purchase process but also after it while evaluating customer feedback (Vesanen, 2007). Thus, in this paper, personalization is considered as a process during which information gathered from customers is used to create personalized proposition for the satisfaction of specific customer needs.
Expression of personalization in the context of services. Service personalization is related to the adaptive behaviour of the company's representative who participates in service delivery process (Gwinner, Bitner, Brown \& Kumar, 2005). Shen \& Ball (2009) analyse such adaptive behaviour as a composition of two dimensions:

- Interpersonal adaptive behaviour - verbal and nonverbal communication of the company's representative with a customer during the service delivery.

- Service-offering adaptive behaviour - service proposal is adapted according to the customer expectations and the personal experience of company's representative.

However, other researchers state that personalization in service delivery is also related to the thorough analysis of customer data (Peltier, Schibrowsky \& Schultz, 2003; Simonson, 2005) and particular psychological aspects (Shamdasani \& Balakrishnan, 2000), such as communication style, disclosure, sympathy, similarity with a customer, etc. Wall \& Berry (2007) emphasize the importance of personalized physical environment, which influences the emotional state of the customer.

One of the possible approaches towards the implementation of the personalization process is the application of personalized interaction. It is considered as interaction between a company and a customer, which is based on mutual understanding, goodwill and feedback.

According to the above-mentioned aspects, it is clear that personalized interaction between a service company and a customer is a complex construct. It is described as the interaction, which is based on mutual understanding, goodwill, feedback and analysis (Johnson \& Nunes, 2003). The highest emphasis is given to the emotional relations between a customer and a company. Shamdasani \& Balakrishnan (2000) propose that three dimensions describe personalized interaction:

- Personalized contact. Interpretation of the dimension is similar to Vesanen (2007) insights that better preference match, better products, better customer service, better communication, and better experience are considered as elements that can create benefits for the customer. It is related with the communication style between the customer and the employee. According to Shamdasani \& Balakrishnan (2000), personalized contact is composed of five elements: expertize, similarity, knowledge of customer, friendliness, disclosure.

- Personalized physical environment is related to the surroundings where the service delivery process proceeds. Usually, the attractiveness and convenience to the customer of physical environment leads to a positive emotional state. Personalized physical environment includes two dimensions: ambience and symbols and artefacts.

- Customer environment and its attractiveness to the customer depend on his / her personal characteristics, such as social class, nationality, lifestyle, values, etc. It is the place where service customer communicates with other customers. Customer environment consists of two dimensions: similarity and interpersonal communication.

Personalized propositions create higher value to customers and are considered as the added value, which can lead to the intention to pursue long-term relationships with the company (Agustin \& Singh, 2005; Yoo \& Minjung, 
2016). Piccoli et al., 2017). Customer value from long-term relationships with a company can be related not only to the personalized service product, but also to the personalized relationships (Hennig-Thurau et al., 2002). The effect of personalization in the context of relationships is usually based on the emotional customer attachment with the company. Such attachment is reached via direct contact between the customer and the employee who participates in a service delivery via customer societies or special events.

Relationship quality. One of the ways to reach successfulness in customer-company relationship marketing is to guarantee implementation of the relevant personalization process (Shamdasani \& Balakrishnan, 2000). Udorn et al. (1998), Shamdasani \& Balakrishnan (2000) emphasize that personalized interaction between a company and a customer leads to better relationship quality and encourage customers to become loyal to a company.

Ball et al. (2006) describe personalized relationship quality as positively influencing customer loyalty, and highlight that its dimension trust is the most important. According to Morgan \& Hunt (1994), trust is "confidence in an exchange partner's reliability and integrity". It has a high impact on relationships longevity and customers intentions to develop relationships with a company in the future. Ball, Coelho \& Machas (2004), Leverin \& Liljander (2006), Roman (2012) highlight that trust in the service company depends on the competencies of the service provider and other intangible aspects, such as company's image, reputation, etc.

Izquierdo \& Cillan (2004) distinguish emotional commitment, which is reached during the process of service personalization. It can be described as collaboration, which allows reaching particular goals for both participating parties. According to Walter, Mueller \& Helfert (2011), Brown, Lusch \& Nicholson (1995), commitment is understood as a wish of interested parties to maintain relationships because of the confidence that this is mutually valuable. Pritchard, Havitz \& Howard (1999) state that one of the most important factors influencing commitment is avoidance of changes, which would cause emotional and financial costs. However, Leverin \& Liljander (2006), Shen \& Ball (2009) argue that commitment occurs when relationships with the customer are important to the company (and vice versa) and this guarantees maximum efforts to develop them.

Walter et al. (2011), Yoo \& Minjung (2016) argue that in case of personalized services customer satisfaction is a prerequisite to retain customers and develop long-term relationships with them. Satisfaction is influenced by the congruence between the customer expectations and the customer experience from services (Rod et al., 2016). Thus, according to Walter et al. (2011), satisfaction is related to the professional level of the exchange process as well as to the clearness of relationships. Therefore, it is necessary to understand customer needs in order to reach customer satisfaction with services and evaluation of relationships as of high professional level (Hennig-Thurau et al., 2002; Moore, Moore \& Capella, 2005; Leverin \& Liljander, 2006; Roman, 2012).

Relationship results. Studies performed by Ball et al. (2006) confirm that service personalization encourages the customer to become loyal to both the company and the employee who participates in a service delivery. The division of relationship results into two dimensions is also confirmed by research of different authors (for example, Leverin \& Liljander (2006), Bagdoniene \& Sliziene (2002), etc.) who analyze customer loyalty to a service company. According to Bagdoniene \& Sliziene (2008), Hanzah et al. (2016), Piccoli et al. (2017), the employee who participates in the service delivery is considered as a necessary resource for the development of long-term relationships with customers. Customers often identify the service company's employee with the company itself and with services they deliver. Leverin \& Liljander (2006) describe customer loyalty as a wish and willingness to be a permanent customer in the longterm period, which is expressed by purchase of services from the company and intentions to recommend it to friends and colleagues. Thus, in this paper customer loyalty is considered as a construct, which consists of two dimensions: loyalty to the service company and loyalty to the employee.

Analysis of the scientific research on personalization shows that relations between the three above mentioned theoretical constructs (personalized interaction, relationship quality and relationship results) exist:

- Relations between particular dimensions of the personalized interaction and particular dimensions of the relationship quality are investigated in research performed by Shamdasani \& Balakrishnan (2000), Coulter \& Coulter (2002), Moore et al. (2005), Qin, Zhao \& Yi (2009); Spake \& Megehee (2010); Lacey (2007), Walter et al. (2011), Udorn et al. (1998), Wall \& Berry (2007), Izquierdo \& Cillan (2004).

- Relations between particular dimensions of the relationship quality and the relationship results in the context of personalization are reasoned by Ball et al. (2006), Leverin \& Liljander (2006), Roman (2012), Ball et al. (2004), Hennig-Thurau et al. (2002), Moore et al. (2005), Ball et al. (2006), Yoo \& Minjung (2016).

- Relations between personalized interaction and relationship dimensions are analysed in the study of Moore $e t$ al. (2005).

However, analysis of these studies allows stating that they do not reveal the holistic view on how personalized interaction influence relationship quality and relationship results. They are somewhat fragmented because authors generally choose to analyse separate dimensions of the three constructs and relations between them.

\section{Research Design}

The importance of personalization and development of long-term relationships with customers highly depend on the level of personal contact with the service customers. Analysis of the research related to the investigation of relations between personalization and long-term relationships (see, e.g., Ball et al., 2006; Shen \& Ball, 2009; Gwinner et al., 2005) are somewhat limited, fragmented, especially in case of the high-contact services.

Thus, hair salon and services of hair stylists were chosen as a case of high-contact services (Shamdasani \& Balakrishnan, 2000). According to Chase (2010), it is considered that high-contact services require:

- physical participation of the customer in the service delivery process (in this case the customer has to come and stay in the hair salon until the end of the service delivery), 
- active contact with the person who delivers service (in this case - with the hair stylist),

- intensive interactions with other customers as well as physical surroundings.

With reference to the above-mentioned characteristics of the high-contact services, it is stated that a case of hair salon, particularly services of hair stylists, allows revealing the expression of personalization while developing long-term relationships with customers.

The aim of the empirical research was to determine the effect of the hair stylist services' personalization on long-term relationships with the hair salon customers. In particular, authors sought to determine relations between personalized interaction between the customer and the company and longterm relationships in a case of hair salon (services of hair stylist).

The quantitative research method - online questionnaire survey - was chosen as an appropriate method to gather research data. However, in such situation target respondents were selected using convenience sample selection method. Since majority of adults periodically visit hairdresser or hair stylist, it was considered that the target population would be reached.

The research instrument - questionnaire - was composed of the two major parts. The first part was intended to gather information about demographic and behavioural characteristics of respondents. The second part - to measure constructs which were discussed in the theoretical part and were necessary to reach the research aim. The set of items for the measurement of personalized interaction dimensions was adapted from Shamdasani \& Balakrishnan (2000): personalized contact is measured with 18 items scale, personalized physical environment - with 6 items scale and customer environment - with 6 items scale. Scales for the measurement of satisfaction (4 items) and trust (6 items) dimensions of relationship quality was adapted from Shamdasani \& Balakrishnan (2000), Ranaweera \& Prabhu (2003) and scale for the commitment (6 items) measurement was adapted from Walter et al. (2011). The measurement of the relationship results dimensions is based on scales presented by Ball et al. (2006) and Leverin \& Liljander (2006). Both loyalty to the hair stylist and loyalty to the hair salon is measured by 4 items scales. Each item was asked to rate on a 5-point Likert-type scale ranging from 1 ("Totally disagree") to 5 ("Totally agree").

Invitations to participate in the survey were sent via Facebook, emails, forums. During the research period, a total number of 409 questionnaires was fully filled and considered as suitable for the further analysis. The majority of respondents was female (75.1 percent), male respondents comprised 24.9 percent in the sample. The dominant age group of respondents was 26-35 years old (38.1 percent), 29.3 percent of respondents were younger adults (age group of 1825 years), older respondents of age between 36-45 years comprised 19.8 percent and older than $46-12.7$ percent of the sample.

\section{Research Results}

The first part of the research results analysis presents behavioural characteristics of respondents. The second part of the research results analysis is devoted to the exploration of different research constructs. Exploratory factor analysis (method of principal components with Varimax rotation) is applied with the aim to create smaller set of correlated items into factors that explain the largest variance among items. After it, results of regression analysis are presented with the aim to test relations between the analysed constructs.

\section{Behavioural Characteristics of Respondents}

Table 1 presents information about how often respondents visit their hair stylists.

Frequency of the Hair Stylist Visits

\begin{tabular}{|l|l|c|c|c|}
\hline \multirow{2}{*}{ Frequency of attendance } & \multicolumn{2}{c|}{ Gender } & \multirow{2}{*}{ Total } \\
\cline { 3 - 4 } & & Female & Male & \\
\hline \multirow{2}{*}{ Several times per month } & $\mathrm{N}$ & 5 & 8 & 13 \\
& $\%$ & 1.6 & 7.8 & 3.2 \\
\hline \multirow{2}{*}{ Once per month } & $\mathrm{N}$ & 72 & 32 & 104 \\
& $\%$ & 23.5 & 31.4 & 25.4 \\
\hline \multirow{2}{*}{ Several times per half a year } & $\mathrm{N}$ & $\mathbf{1 3 0}$ & $\mathbf{4 0}$ & $\mathbf{1 7 0}$ \\
& $\%$ & $\mathbf{4 2 . 3}$ & $\mathbf{3 9 . 2}$ & $\mathbf{4 1 . 6}$ \\
\hline \multirow{2}{*}{ Several times per year } & $\mathrm{N}$ & 63 & 16 & 79 \\
& $\%$ & 20.5 & 15.7 & 19.3 \\
\hline \multirow{2}{*}{ Once per year or rarely } & $\mathrm{N}$ & 37 & 6 & 43 \\
& $\%$ & 12.1 & 5.9 & 10.5 \\
\hline \multirow{2}{*}{ Total } & $\mathrm{N}$ & 307 & 102 & 409 \\
& $\%$ & 100.0 & 100.0 & 100.0 \\
\hline
\end{tabular}

It can be seen that the majority of them $(41.6 \%)$ visit their hair stylist several times per half a year. The lowest number of respondents visits their hair stylist several times per month $(3.2 \%)$. Comparison of the behavioural characteristics of men and women shows that men visit their hair stylist relatively more often than women do. The lowest number of women respondents goes to their hair stylist several times per month $(1.6 \%)$, the lowest number of men respondents - once per year of rarely $(6 \%)$.

Figure 1 demonstrates the mean scores of respondents' agreements with the statements on what they feel about the visit to their hair stylist. Respondents associate the visit to hair stylist with the "visit which raises positive feelings" (3.89), "pleasant visit which I always wait for" (3.83), "visit during which I relax" (3.78).

It is like a meeting with a friend who
knows me very well
Vizit which raise the feel of pride
because I can afford it
Vizit which shows my social status

Vizit during which I feel at ease

Vizit which raises positive feelings

Vizit during which I relax

Vizit during which I feel like exceptional person

Variation in my solial life because I can socialize

Pleasant vizit I always wait for

Part of my personal lifestyle

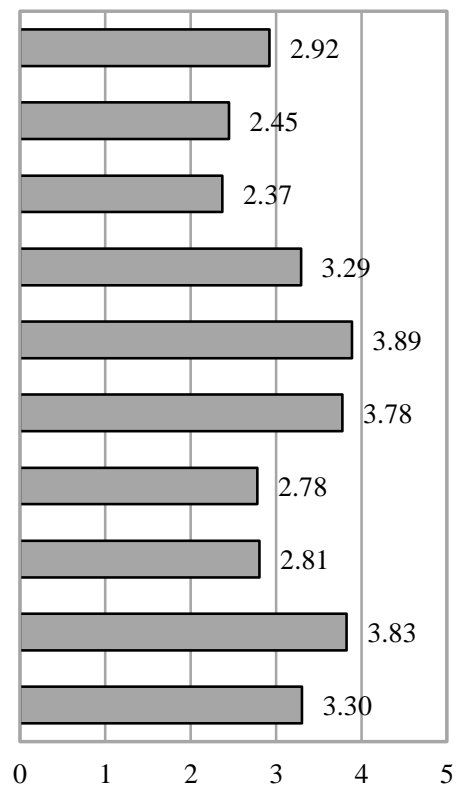

Figure 1. Behavioural characteristics of respondents 
They do not consider the visit to their hair stylist as a social status symbol (2.37) or confirmation that they can afford it (2.45). Such results show that services of hair stylists are not considered as luxury services, but more like necessary services, which are pleasant and relaxing.

\section{Factor Analysis}

Table 2 presents results of the factor analysis. First, dimensions of the "personalized interaction between a hair stylist and a customer" were analysed. During the factor analysis, five factors describing the element "personalized contact" were extracted.

Table 2

Results of Factor Analysis

\begin{tabular}{|c|c|c|c|c|}
\hline Factors & Measured items & $\begin{array}{l}\text { Factorial } \\
\text { weights }\end{array}$ & $\begin{array}{l}\text { Factor } \\
\text { Cronbach's } \\
\text { alpha }\end{array}$ & $\begin{array}{c}\text { Variance } \\
\text { explained by } \\
\text { the factor, } \%\end{array}$ \\
\hline \multicolumn{5}{|c|}{ Personalized interaction between the hair stylist and the customer } \\
\hline \multicolumn{5}{|l|}{ Personalized contact } \\
\hline $\begin{array}{l}\text { Expertise of the hair } \\
\text { stylist }(F 1)\end{array}$ & $\begin{array}{l}\text { My hair stylist is highly qualified; My hair stylist has received } \\
\text { substantial training; My hair stylist has many years of experience; My } \\
\text { hair stylist is highly skilled. }\end{array}$ & $0.744-0.823$ & 0.829 & 31.27 \\
\hline $\begin{array}{l}\text { Disclosure of the hair } \\
\text { stylist }(F 2)\end{array}$ & $\begin{array}{l}\text { I openly discuss personal matters with my hair stylist; May hair stylist } \\
\text { tries to establish a personal relationship with me; My hair stylist and I can } \\
\text { talk about anything; My hair stylist recognizes me as a regular customer. }\end{array}$ & $0.491-0.851$ & 0.763 & 11.64 \\
\hline $\begin{array}{l}\text { Customer's similarity } \\
\text { with the hair stylist }(F 3)\end{array}$ & $\begin{array}{l}\text { Dressing style of my hair stylist looks in good taste; My hair stylist and I } \\
\text { have similar interests and hobbies; My hair stylists and I belong to the } \\
\text { same age group; I like appearance of my hair stylist; My hair stylist } \\
\text { understands my specific needs. }\end{array}$ & $0.448-0.778$ & 0.743 & 7.99 \\
\hline $\begin{array}{l}\text { Friendliness of the hair } \\
\text { stylist }(F 4)\end{array}$ & $\begin{array}{l}\text { My hair stylist is friendly; My hair stylist is difficult to talk with (R); I } \\
\text { like mannerism and behaviour of my hair stylist. }\end{array}$ & $0.633-0.719$ & 0.739 & 6.80 \\
\hline $\begin{array}{l}\text { Knowledge of the hair } \\
\text { stylist }(F 5)\end{array}$ & $\begin{array}{l}\text { My hair stylist doesn't know my specific requirements without me } \\
\text { having to tell her / him each time I go (R); My hair stylist has limited } \\
\text { knowledge of hair styling, haircare, hair products, etc. (R). }\end{array}$ & $0.624-0.804$ & 0.728 & 5.78 \\
\hline KMO & 0.845 & \multicolumn{2}{|c|}{ Total variance explained, \% } & 63.48 \\
\hline \multicolumn{5}{|c|}{ Personalized physical environment } \\
\hline $\begin{array}{l}\text { Symbols and artefacts } \\
\text { of the hair salon }(F 1)\end{array}$ & $\begin{array}{l}\text { My hair salon has modern-looking furniture and decor; My hair salon has } \\
\text { an impressive and cosy reception area; I feel that everybody takes care of } \\
\text { me in my hair salon. }\end{array}$ & $0.763-0.830$ & 0.803 & 58.11 \\
\hline $\begin{array}{l}\text { Ambience of the hair } \\
\text { salon }(F 2)\end{array}$ & $\begin{array}{l}\text { My hair salon is neither too cold nor too warm; My hair salon is very neat } \\
\text { and clean; There is ample and comfortable lighting in my hair salon; My } \\
\text { hair salon has a relaxed atmosphere. }\end{array}$ & $0.629-0.897$ & 0.832 & 13.36 \\
\hline KMO & 0.832 & \multicolumn{2}{|c|}{ Total variance explained, \% } & 71.47 \\
\hline \multicolumn{5}{|l|}{ Customer environment } \\
\hline $\begin{array}{l}\text { Customer similarity } \\
(F 1)\end{array}$ & $\begin{array}{l}\text { Me and other customers in my hair salon belong to the similar age group; } \\
\text { Me and other customers in my hair salon are informed about new trends } \\
\text { in beauty and fashion; Me and other customers in my hair salon have } \\
\text { similar interests and hobbies; I like mannerism and behaviour of other } \\
\text { customers in my hair salon. }\end{array}$ & $0.612-0.812$ & 0.759 & 36.31 \\
\hline $\begin{array}{l}\text { Interpersonal } \\
\text { communication }(F 2)\end{array}$ & $\begin{array}{l}\text { Other customers at my hair salon are easy to talk with; I enjoy socializing } \\
\text { with other customers in my hair salon. }\end{array}$ & $0.850-0.920$ & 0.853 & 32.43 \\
\hline KMO & 0.802 & \multicolumn{2}{|c|}{ Total variance explained, $\%$} & 68.74 \\
\hline \multicolumn{5}{|c|}{ Relationship quality } \\
\hline Trust & $\begin{array}{l}\text { My hair stylist is reliable; My hair stylist is trustworthy; I have full } \\
\text { confidence in my hairs stylist; I have no doubts about the quality of the } \\
\text { equipment and hair products used by my hair stylist; The favourable } \\
\text { customer environment reinforces my confidence in the hair salon; I know } \\
\text { I will always receive the best service at my hair salon. }\end{array}$ & $0.749-0.838$ & 0.895 & - \\
\hline KMO & 0.846 & \multicolumn{2}{|c|}{ Total variance explained, $\%$} & 65.87 \\
\hline Satisfaction & $\begin{array}{l}\text { I am sure I made the right decision in choosing my hair stylist; Services } \\
\text { of my hair stylist meet my expectations; I am satisfied with services in my } \\
\text { hair salon; I like environment in my hair salon. }\end{array}$ & $0.681-0.854$ & 0.803 & - \\
\hline KMO & 0.746 & \multicolumn{2}{|c|}{ Total variance explained, $\%$} & 64.91 \\
\hline Commitment & $\begin{array}{l}\text { In my hair salon I feel like "a member of the family"; I attempt to stay in } \\
\text { good relations with my hair stylist; Relations with my hair stylist are } \\
\text { important to me; It would be difficult to change hair stylist; I do not search } \\
\text { for new hair stylist; I am happy to be a customer of my hair salon; My life } \\
\text { would change if I had to change my hair stylist. }\end{array}$ & $0.618-0.813$ & 0.826 & - \\
\hline KMO & 0.821 & \multicolumn{2}{|c|}{ Total variance explained, \% } & 53.46 \\
\hline \multicolumn{5}{|c|}{$\begin{array}{l}\text { Relationship results } \\
\end{array}$} \\
\hline $\begin{array}{l}\text { Loyalty to the hair salon } \\
(F 1)\end{array}$ & $\begin{array}{l}\text { I will continue to visit my present hair salon in future; I will recommend my } \\
\text { hair salon to my friends and family members; I will switch to another hair } \\
\text { salons in future (R); I will complain about my hair salon to others }(\mathrm{R}) \text {. }\end{array}$ & $0.802-0.879$ & 0.816 & 35.77 \\
\hline $\begin{array}{l}\text { Loyalty to the hair } \\
\text { stylist }(F 2)\end{array}$ & $\begin{array}{l}\text { I will continue to visit my present hair stylist in future; I will recommend } \\
\text { my hair stylist to my friends and family members; I will switch to other hair } \\
\text { stylist in future (R); I will complain about my hair stylist to others (R). }\end{array}$ & $0.659-0.906$ & 0.768 & 35.45 \\
\hline KMO & 0.677 & \multicolumn{2}{|c|}{ Total variance explained, $\%$} & 71.22 \\
\hline
\end{tabular}

(R): Item is reverse coded 
They describe 63.48 percent of total variance. KayserMayer-Olkin (KMO) test value is 0.845 and demonstrates a good adequacy of the factor analysis. It must be mentioned that factor structure changed in comparison to the theoretical assumptions. Items, which were attributed to the element "knowledge about the customer", went to different factors after factor analysis. However, the meaning of items corresponds to their attribution. Besides, a new factor, which includes both knowledge about the customer expectations and professional knowledge of the hair stylist, was formed ("Knowledge of the hair stylist"). Factorial weights of the items in cases of all factors are in the range of allowed level of factorial weight, i.e. not lower than 0.4 (Piligrimiene, 2016) (accordingly, 0.744-0.823; 0.491-0.851; 0.448-0.778; 0.633$0.719 ; 0.624-0.804)$. Cronbach's alphas (accordingly, 0.829; $0.763 ; 0.743 ; 0.739 ; 0.728)$ show the good level of internal consistency. During the factor analysis, two factors describing dimension "personalized physical environment" were derived. Factors are formed by items which were intended to measure "symbols and artefacts of the hair salon" $(F 1)$ and "ambience of the hair salon" $(F 2)$. Two factors together explain 71.47 percent of the variances, $K M O$ value is quite high (0.832), which show resultative factor analysis. Scale's internal consistency is reasoned by high values of Cronbach's alphas (accordingly, 0.803 and 0.832). A similar situation is with the third dimension of the personalized interaction between the hair stylist and the customer, i.e. "Customer environment" - two factors "customer similarity" $(F 1)$ and "interpersonal communication" $(F 2)$ were derived which explain 68.74 percent of total variance, $K M O$ is equal to 0.802. Cronbach's alphas are high enough as well (accordingly, 0.759 and 0.853).

Considering the fact that for the measurement of relationship quality dimensions well-known and validated scales were used, the factor analysis was accomplished separately for trust, satisfaction and commitment. As can be seen from the Table 2 these scales, as expected, ideally match and compose one factor in all three cases (Cronbach's alphas are $0.895,0.803,0.826)$ and show good adequacy (KMO values are $0.846 ; 0.746 ; 0.821)$ and the acceptable level of the explained variances $(65.87 ; 64.91 ; 53.46$ percent $)$.

As expected items, which measure relationship results formed two factors - "loyalty to the hair salon" (F1; Cronbach's alpha equals 0.816 ) and "loyalty to the hair stylist" (F2; Cronbach's alpha equals 0.768). KMO value demonstrates acceptable adequacy of factor analysis (0.677), both factors explain 71.22 percent of total variance.

\section{Regression Analysis}

While seeking to investigate how personalized interaction between the hair stylist and the customer affects long-term relationships with the customer, multiple linear regression analysis was applied. Before these tests, hypotheses about normal distribution of the dependent variables were tested (Kolmogorov-Smirnov test). In all cases, the null hypothesis stating that the distribution of variables is normal was retained. All model requirements for multicollinearity and heteroscedasticity of data were fulfilled.

Table 3 presents results of the regression models' testing, where independent variables were elements of personalized interaction dimensions and dependent variables - relationship quality dimensions. After these nine models, generalized regression models are provided, where independent variables are dimensions of personalized interaction.

According to the data, provided in the Table 3, it is stated that:

- Satisfaction and trust is influenced by all elements of personalized contact. Expertize of the hair stylist is the element which has the strongest impact on trust $(\beta=0.458, p$ $<0.001)$ and satisfaction $(\beta=0.420, p<0.001)$. Disclosure of the hair stylist is the element which has the strongest impact on commitment $(\beta=0.495, p<0.001)$. However, commitment is not influenced by knowledge of the hair stylist ( $\beta=-0.034, p>0.05)$. Coefficients of $R^{2 a d j}$ show that these regression models are suitable for the linear influence measurement and on average explain $45.8 \%$ of trust variance, $38.9 \%$ of satisfaction variance and $46.2 \%$ of commitment variance.

- All elements of personalized physical environment have significant influence on all dimensions of relationship quality. Ambience of the hair salon has stronger influence on trust $(\beta=0.541, p<0.001)$ then symbols and artefacts of the hair salon $(\beta=0.264, p<0.001)$. An opposite situation is in the case of commitment, here the stronger influencer is element symbols and artefacts of the hair salon ( $\beta=0.456, p<0.001)$. Both elements have moderate but significant influence on satisfaction (in case of ambience of hair salon $(\beta=0.531, p<0.001$; in case of symbols and artefacts of the hair salon $(\beta=0.479, p<0.001)$. On average, these regression models explain $36.0 \%$ of trust, $50.9 \%$ of satisfaction and $26.1 \%$ of commitment variance.

- Regression models analysing influence of customer environment elements on dimensions of relationship quality formally meet all required assumptions for model fit. However, $R^{2 a d j}$ coefficients are quite low (see Table 3), thus, influence of customer environment on relationship quality is questionable. Customer similarity has weak, but significant influence on trust $(\beta=0.212, p<0.001)$, satisfaction $(\beta=0.293, p<0.001)$ and commitment $(\beta=$ $0.311, p<0.001)$. Interpersonal communication also has weak, but significant influence on satisfaction $(\beta=0.165, p<$ $0.001)$ and commitment $(\beta=0.265, p<0.001)$, but does not influence trust $(\beta=0.036, p>0.05)$. 
Table 3

Results of Regression Analysis When Dependent Variables Are Dimensions of Relationship Quality

\begin{tabular}{|c|c|c|c|c|c|c|c|}
\hline \multirow{3}{*}{\multicolumn{2}{|c|}{ Predictors }} & \multicolumn{6}{|c|}{ Dependent variable } \\
\hline & & \multicolumn{2}{|c|}{ Trust } & \multicolumn{2}{|c|}{ Satisfaction } & \multicolumn{2}{|c|}{ Commitment } \\
\hline & & Beta & Sig. & Beta & Sig. & Beta & Sig. \\
\hline \multicolumn{8}{|l|}{ Elements of personalized contact } \\
\hline \multicolumn{2}{|l|}{ Expertise of hair stylist } & 0.458 & $<0.001$ & 0.420 & $<0.001$ & 0.304 & $<0.001$ \\
\hline \multicolumn{2}{|l|}{ Disclosure of hair stylist } & 0.165 & $<0.001$ & 0.272 & $<0.001$ & 0.495 & $<0.001$ \\
\hline \multicolumn{2}{|l|}{ Customer's similarity with hair stylist } & 0.150 & $<0.001$ & 0.233 & $<0.001$ & 0.243 & $<0.001$ \\
\hline \multicolumn{2}{|l|}{ Friendliness of hair stylist } & 0.419 & $<0.001$ & 0.285 & $<0.001$ & 0.253 & $<0.001$ \\
\hline \multicolumn{2}{|l|}{ Knowledge of hair stylist } & 0.171 & $<0.001$ & 0.102 & $<0.001$ & -0.034 & 0.357 \\
\hline \multicolumn{2}{|c|}{ Adjusted $R$ square } & \multicolumn{2}{|c|}{$\mathbf{0 . 4 5 8}$} & \multicolumn{2}{|c|}{0.389} & \multicolumn{2}{|c|}{0.462} \\
\hline \multirow[t]{2}{*}{ ANOVA } & $\boldsymbol{F}$ & \multicolumn{2}{|c|}{70.033} & \multicolumn{2}{|c|}{53.098} & \multicolumn{2}{|c|}{69.358} \\
\hline & Sig. & \multicolumn{2}{|c|}{$<0.001$} & \multicolumn{2}{|c|}{$<0.001$} & \multicolumn{2}{|c|}{$<0.001$} \\
\hline \multicolumn{8}{|l|}{ Elements of personalized physical environment } \\
\hline \multicolumn{2}{|l|}{ Symbols and artefacts of hair salon } & 0.264 & $<0.001$ & 0.479 & $<0.001$ & 0.456 & $<0.001$ \\
\hline \multicolumn{2}{|l|}{ Ambience of hair salon } & 0.541 & $<0.001$ & 0.531 & $<0.001$ & 0.239 & $<0.001$ \\
\hline & Adjusted $R$ square & \multicolumn{2}{|c|}{0.360} & \multicolumn{2}{|c|}{$\mathbf{0 . 5 0 9}$} & \multicolumn{2}{|c|}{0.261} \\
\hline ANOVA & $F$ & \multicolumn{2}{|c|}{115.791} & & 788 & & \\
\hline Elements of customer environment & & & & & & & \\
\hline Customer similarity & & 0.212 & $<0.001$ & 0.293 & $<0.001$ & 0.311 & $<0.001$ \\
\hline Interpersonal communication & & 0.036 & 0.454 & 0.165 & $<0.001$ & 0.265 & $<0.001$ \\
\hline Adj & ted $R$ square & & & & & & \\
\hline ANOVA & $\boldsymbol{F}$ & & & & & & \\
\hline & Sig. & & 01 & & 01 & & \\
\hline Dimensions of personalized interaction between hair stylist and c & stomer & & & & & & \\
\hline Personalized contact & & 0.969 & $<0.001$ & 0.613 & $<0.001$ & 0.895 & $<0.001$ \\
\hline Personalized physical environment & & 0.514 & $<0.001$ & 0.776 & $<0.001$ & 0.261 & $<0.001$ \\
\hline Customer environment & & 0.120 & 0.034 & 0.051 & 0.310 & 0.318 & $<0.001$ \\
\hline Adj & ted $R$ square & & & & & & \\
\hline ANOVA & $\boldsymbol{F}$ & & 568 & & 523 & & \\
\hline & Sig. & & 01 & & 01 & & 01 \\
\hline
\end{tabular}

For the better generalization of research results, it was decided to analyse influence of all dimensions of personalized contact on relationship quality dimensions. It was determined that personalized contact has the strong influence in cases of trust $(\beta=0.969, \mathrm{p}<0.001)$ and commitment $(\beta=0.895, \mathrm{p}<$ $0.001)$, moderate influence in the case of satisfaction $(\beta=$ $0.613, \mathrm{p}<0.001)$. Personalized physical environment has strong influence on satisfaction $(\beta=0.776, p<0.001)$, moderate influence on trust $(\beta=0.514, \mathrm{p}<0.001)$ and weak but statistically significant influence on commitment $(\beta=$ $0.261, \mathrm{p}<0.001)$. Customer environment has weak but statistically significant impact on trust $(\beta=0.120, \mathrm{p}<0.05)$ and commitment $(\beta=0.318, \mathrm{p}<0.001)$, but has no impact on satisfaction $(\beta=0.051, \mathrm{p}>0.05)$. Table 4 presents results of regression analysis where dependent variables are relationship results - loyalty to the hair salon and loyalty to the hair stylist.

The first part of the Table 4 is dedicated to analyse influence of relationship quality dimensions on relationship results:

- Trust has no influence on loyalty to the hair salon $(\beta=$ $0.071, p>0.05)$ and has very weak significant influence on loyalty to the hair stylist $(\beta=0.146, p<0.001)$.

- Influence of commitment on loyalty to the hair salon $(\beta=0.094, p<0.05)$ and the hair stylist $(\beta=0.118, p=0.001)$ is also significant, but weak.

- Satisfaction has influence on loyalty to the hair salon $(\beta=0.252, p<0.001)$ and the hair stylist $(\beta=0.228, p<$ $0.001)$. This influence is also weak, but it is stronger than influence of trust and commitment.
- Coefficients $R^{2 a d j}$ are low in both cases, but they are on acceptable level.

Table 4

Results of Regression Analysis When Dependent Variables Are Relationship Results

\begin{tabular}{|c|c|c|c|c|c|}
\hline \multirow{3}{*}{\multicolumn{2}{|c|}{ Predictors }} & \multicolumn{4}{|c|}{ Dependent variable } \\
\hline & & \multicolumn{2}{|c|}{ Loyalty to hair salon } & \multicolumn{2}{|c|}{ Loyalty to hair stylist } \\
\hline & & Beta & Sig. & Beta & Sig. \\
\hline \multicolumn{6}{|c|}{ Dimensions of relationship quality } \\
\hline \multicolumn{2}{|c|}{ Trust } & 0.071 & 0.096 & 0.146 & $<0.001$ \\
\hline \multicolumn{2}{|c|}{ Satisfaction } & 0.252 & $<0.001$ & 0.228 & $<0.001$ \\
\hline \multicolumn{2}{|c|}{ Commitment } & 0.094 & 0.010 & 0.118 & 0.001 \\
\hline \multicolumn{2}{|c|}{ Adjusted $R$ square } & \multicolumn{2}{|c|}{0.264} & \multicolumn{2}{|c|}{0.351} \\
\hline \multirow[t]{2}{*}{ ANOVA } & $F$ & \multicolumn{2}{|c|}{49.798} & \multicolumn{2}{|c|}{74.716} \\
\hline & Sig. & \multicolumn{2}{|c|}{$<0.001$} & \multicolumn{2}{|c|}{$<0.001$} \\
\hline \multicolumn{6}{|c|}{$\begin{array}{l}\text { Dimensions of personalized interaction between hair stylist and } \\
\text { customer }\end{array}$} \\
\hline \multicolumn{2}{|c|}{ Personalized contact } & 0.299 & 0.001 & 0.749 & $<0.001$ \\
\hline \multicolumn{2}{|c|}{$\begin{array}{l}\text { Personalized } \\
\text { physical } \\
\text { environment }\end{array}$} & 0.289 & $<0.001$ & 0.088 & 0.101 \\
\hline \multicolumn{2}{|c|}{$\begin{array}{l}\text { Customer } \\
\text { environment }\end{array}$} & -0.049 & 0.322 & -0.087 & 0.061 \\
\hline \multicolumn{2}{|c|}{ Adjusted $R$ square } & \multicolumn{2}{|c|}{0.259} & \multicolumn{2}{|c|}{0.288} \\
\hline \multirow[t]{2}{*}{ ANOVA } & $\boldsymbol{F}$ & \multicolumn{2}{|c|}{56.803} & \multicolumn{2}{|c|}{46.778} \\
\hline & Sig. & \multicolumn{2}{|c|}{$<0.001$} & \multicolumn{2}{|c|}{$<0.001$} \\
\hline
\end{tabular}

The second part of the Table 4 presents analysis of regression models where independent variables are generalized dimensions of personalized interaction between the hair stylist and the customer:

- Loyalty to the hair salon is moderately influenced by personalized contact $(\beta=0.299, p=0.001)$ and personalized physical environment $(\beta=0.289, p<0.001)$, but 
not influenced by customer environment $(\beta=-0.049, p<$ $0.05)$.

- Loyalty to the hair stylist is strongly influenced only by personalized contact $(\beta=0.749, p<0.001)$, not influenced by personalized physical environment $(\beta=0.088$, $p<0.05)$ and customer environment $(\beta=-0.087, p<0.05)$.

- Coefficients $R^{2 a d j}$ are low in both cases, but they are on acceptable level.

\section{Conclusions}

The ongoing discussions on personalization confirm the importance of the phenomenon, especially in the context of services. In the paper, the assumption that personalized value propositions create higher value for the customer and thus let companies reach competitive advantage is reasoned. The essential reason to implement service personalization process via personalized interaction between the customer and the service company employee is related to the satisfaction of the individual customer needs. Personalization is considered as an effective means to increase customer satisfaction, trust and commitment, which is necessary for the development of longterm relationships with customers.

The paper reasons that the effectiveness of personalization depends on the expression of personalized interaction dimensions (personalized contact, personalized physical environment, and customer environment) during the service delivery process and its attractiveness to the particular customer. The ambiguity in scientific research exists when researchers describe results of personalized interaction between a customer and a company. After a thorough analysis of them, it is decided that relationship quality is considered as a construct, consisting of three dimensions - satisfaction, trust and commitment. Customer loyalty in the case of services is divided into two dimensions - loyalty to the company and loyalty to the employee. The fragmentary scientific research on relations between personalized interaction dimensions, relationship quality dimensions and loyalty dimensions encouraged authors of the paper to decide to test them all in a case of hair salon (particularly, hair stylist) services.

Empirical research results analysis in terms of relations between dimensions of personalized interaction and dimensions of relationship quality reveals that the personalized contact has the strongest impact on all relationship quality dimensions - trust, satisfaction and commitment. "Expertise of the hair stylist" is considered as the element of personalized contact, which has the strongest impact on customer satisfaction and trust, while the element "disclosure of the hair stylist" is the one influence of which on commitment is quite high, and the element "friendliness of the hair stylist" has influence on trust. Such results distinguish the importance of the hair stylist competence, not only in professional field, but also in interpersonal communication. Since customer trust, satisfaction and commitment is also influenced by the elements of personalized physical environment, it is necessary to pay attention to physical aspects of the hair salon, i.e. temperature, lighting, cleanness as well as to personal attention to customer given not only by hair stylist, but also by other employees which are met during the service delivery process.

As regards relations between relationship quality and relationship results, it was unexpected to detect that relationship quality dimensions such as trust, satisfaction and commitment weakly influence loyalty to the hair salon and loyalty to the hair stylist. It was found that the direct influence of personalized interaction dimensions on relationship results is stronger. The element "personalized contact" has the strongest direct impact on both loyalty to the hair salon and loyalty to the hair stylist. While evaluating the effect of personalized physical environment on relationship results, it was noticed that it has stronger direct impact on loyalty to the hair salon. However, its impact on loyalty to the hair stylist manifests more through relationship quality, but not directly. Customer environment does not influence relationship results.

Since this paper presents results of the pilot research, it is worth to continue empirical verification of the proposed theoretical insights in cases of different high-contact services. This would lead to the verification of the structure of personalized interaction construct. Additionally, it would be worth to test if there are significant differences in regression analysis results when respondents are grouped in terms of gender, age group or other demographic or psychographic characteristics.

\section{References}

Adomavicius, G., \& Tuzhilin, A. (2001). Expert-Driven Validation of Rule-Based User Models in Personalization Applications. Data Mining and Knowledge Discovery, 5(1), 33-58. http://dx.doi.org/10.1023/A:1009839827683

Agustin, C., \& Singh, J. (2005). Curvilinear Effects of Consumer Loyalty Determinants in Relational Exchanges. Journal of Marketing Research, 42(1), 96-108. http://dx.doi.org/10.1509/jmkr.42.1.96.56961

Bagdoniene. L., Sliziene, G. (2002). Rysiu marketingas - siuolaikines paslaugu organizacijos naujoji veiklos filosofija. Organizaciju vadyba: sisteminiai tyrimai, 23, 7-18.

Ball, D., Coelho, P. S., \& Machas, A. (2004). The Role of Communication and Trust in Explaining Customer Loyalty: An Extension to the ECSI Model. European Journal of Marketing, 38(9/10), 1272-1293. http://dx.doi.org/10. 1108/03090560410548979

Ball, D., Coelho, P. S., \& Vilares, M. J. (2006). Service Personalization and Loyalty. Journal of Services Marketing, 20(6), 391-403. http://dx.doi.org/10.1108/08876040610691284

Blom, A. F, \& Monk, J. O. (2007). A Theory of Personalisation of Appearance: Quantitative Evaluation of Qualitatively Derived Data. Behaviour and Information Technology, 26(3), 237-246. http://dx.doi.org/10.1080/01449 290500348168 
Jurate Banyte, Agne Gadeikiene, Ausra Rutelione, Inga Kakneviciene. Expression of Personalization while Developing Long ...

Brown, J. R., Lusch, R. F., \& Nicholson, C. Y. (1995). Power and Relationship Commitment: Their Impact on Marketing Channel Member Performance. Journal of Retailing, 71(4), 363-392. http://dx.doi.org/10.1016/00224359(95)90019-5

Chase, R. B. (2010). Revisiting "Where does the Customer Fit in a Service Operation?" Backgroung and Future Development of Contact Theory. In Maglio, P. P. et al. (eds.), Handbook of Service Science, Springer Science+Business Media, LLC, 11-17.

Coulter, K. S., \& Coulter, R. A. (2002). Determinants of Trust in Service Provider: the Moderating Role of Length of Relationship. Journal of Service Marketing, 16(1), 35-50. http://dx.doi.org/10.1108/08876040210419406

Fiore, A. M., Lee, S. E. \& Kunz, G. (2004). Individual Differences, Motivations, and Willingness to Use a Mass Customization Option. European Journal of Marketing, 38/7, 835-849. http://dx.doi.org/10.1108/0309 0560410539276

Gwinner, K. P., Bitner, M. J., Brown, S. W., \& Kumar, A. (2005). Service Customization through Employee Adaptiveness. Journal of Service Research, 8(2), 131-148. http://dx.doi.org/10.1177/1094670505279699

Hanzah, M. I., Othman, A. K., \& Hassan, F. (2016). Moderating Role of Customer Orientation on the Link between Market Oriented Behaviors and Proactive Service Performance among Relationship Managers and Business Banking Industry. Procedia - Social and Behavioural Sciences, 224, 109-116. http://dx.doi.org/10.1016/j.sbspro.2016.05.412

Hennig-Thurau, T., Gwinner, K. P., \& Gremler, D. D. (2002). Understanding Relationship Marketing Outcomes - An Integration of Relational Benefits and Relationship Quality. Journal of Service Research, 3(4), $230-247$. http://dx.doi.org/10.1177/1094670502004003006

Ho, S.Y. (2006). The Attraction of Internet Personalization to Web Users. Electronic Markets, 16(1), 41-50. http://dx.doi.org/10.1080/10196780500491162

Imhoff, C., Loftis, L., \& Geiger, J. G. (2001). Building the Customer-Centric Enterprise, Data Warehousing Techniques for Supporting Customer Relationship Management. New York: Wiley.

Izquierdo, C., \& Cillán, J. (2004). The Interaction of Dependence and Trust in Long-Term Industrial Relationships. European Journal of Marketing, 38(8), 974-994. http://dx.doi.org/10.1108/03090560410539122

Johnson, B. A., \& Nunes, P. F. (2003). Let's Talk: Applying the Art of Conversation to Customer Contact. In Freeland, J. G. (Ed.), The Ultimate CRM Handbook: Strategies and Concepts for Building Enduring Customer Loyalty and Profitability, McGraw-Hill: New York, 118-125.

Kwon, K., \& Kim, C. (2012). How to Design Personalization in a Context of Customer Retention: Who Personalizes What and to What Extent? Electronic Commerce Research and Applications, 11, 101-116. http://dx.doi.org/10. 1016/j.elerap.2011.05.002

Lacey, R (2007). Relationship Drivers of Customer Commitment. Journal of Marketing Theory and Practice, 15(4), 315333. http://dx.doi.org/10.2753/MTP1069-6679150403

Leverin, A., \& Liljander, V. (2006). Does Relationship Marketing Improve Customer Relationship Satisfaction and Loyalty? International Journal of Bank Marketing, 24(4), 232-251. http://dx.doi.org/10.1108/02652320610671333

Moore, R., Moore, M. L., \& Capella, M. (2005). The Impact of Customer-to-Customer Interactions in a High Personal Contact Service Setting. Journal of Services Marketing, 19/7, 482-491. http://dx.doi.org/10.1108/08876040 510625981

Morgan, R. M., \& Hunt, S. D. (1994). The Commitment - Trust Theory of Relationship Marketing. Journal of Marketing, 58(3), 20-38. http://dx.doi.org/10.2307/1252308

Peltier, J. W., Schibrowsky, J. A., \& Schultz, D. E. (2003). Interactive Integrated Marketing Communication: Combining the Power of IMC, the New Media and Database Marketing. International Journal of Advertising, 22, 93-115.

Petrison, L. A., Blattberg, R. C., \& Wang, P. (1997). Database Marketing - Past, Present and Future. Journal of Interactive Marketing, 11(4), 109-125.

Pierrakos, D., Paliouras, G., Papatheodorou, C., \& Spyropoulos, C. (2003). Web Usage Mining as a Tool for Personalization: A Survey. User Modeling and User-Adapted Interaction, 13, 311-372. http://dx.doi.org/10. 1023/A:1026238916441

Piccoli, G., Lui, T. W., \& Grun, B. (2017). The Impact of IT-Enabled Customer Service Systems on Service Personalization, Customer Service Perceptions, and Hotel Performance. Tourism Management, 59, $349-362$. http://dx.doi.org/10. 1016/j.tourman.2016.08.015

Piligrimiene, Z. (2016). Marketingo tyrimu duomenų analize SPSS programa. Kaunas: Technologija.

Pritchard, M., Havitz, M., \& Howard, D. (1999). Analyzing the Commitment-Loyalty Link in Service Relationships. Journal of the Academy of Marketing Science, 27(3), 333-48. http://dx.doi.org/10.1177/0092070399273004 
Qin, S., Zhao, L., \& Yi, X. (2009). Impacts of Customer Service on Relationship Quality: an Empirical Study in China. Managing Service Quality: An International Journal, 19(4), 391-409. http://dx.doi.org/10.1108/0960452091 0971520

Rajaguru, R. (2016). Role of Value for Money and Service Quality on Behavioural Intention: A Study of Full Service and Low Cost Airlines. Journal of Air Transport Management, 53, 114-122. http://dx.doi.org/10.1016/j.jairtraman. 2016.02.008

Ranaweera, C., \& Prabhu, J. (2003). The Influence of Satisfaction, Trust and Switching Barriers on Customer Retention in a Continuous Purchasing Setting. International Journal of Service Industry Management, 14(4), 374-395. http://dx.doi.org/10.1108/09564230310489231.

Rod, M., Ashill, N. J., \& Gibbs, T. (2016). Customer Perceptions of Frontline Employee Service Delivery: A Study of Russian Bank Customer Satisfaction and Behavioural Intentions. Journal of Retailing and Consumer Services, 30, 212-221. http://dx.doi.org/10.1016/j.jretconser.2016.02.005

Roman, S. (2012). The Impact of Ethical Sales Behaviour on Customer Satisfaction, Trust and Loyalty to the Company: An Empirical Study in the Financial Services Industry. Journal of Marketing Management, 19(9/10), 915-939. http://dx.doi.org/10.1080/0267257X.2003.9728245.

Shamdasani, P. N., \& Balakrishnan A. A. (2000). Determinants of Relationship Quality and Loyalty in Personalized Services. Asia Pacific Journal of Management, 17/3, 399-422. http://dx.doi.org/10.1023/A:1015834214570

Shen, A., \& Ball, D. (2009). Is Personalization of Services Always a Good Thing? Exploring the Role of TechnologyMediated Personalization (TMP) in Service Relationships. Journal of Services Marketing, 23/2, 80-92. http://dx.doi.org/10.1108/08876040910946341

Simonson, I. (2005). Determinants of Customers' Responses to Customized Offers: Conceptual Framework and Research Propositions. Journal of Marketing, 69(1), 32-45. http://dx.doi.org/10.1509/jmkg.69.1.32.55512

Smith, M., \& Colgate, M. (2007). Customer Value Creation: A Practical Framework. Journal of Marketing Theory and Practice, 15(1), 7-23. http://dx.doi.org/10.2753/MTP1069-6679150101

Spake, D. F., \& Megehee, C. M. (2010). Consumer Sociability and Service Provider Expertise Influence on Service Relationship Success. Journal of Services Marketing, 24(4), 314-324. http://dx.doi.org/10.1108/0887604 1011053024

Udorn, P., Bloom, N., \& Zeithaml, A. (1998). Consumer Commitment: A Crucial Connection Between Consumers and Companies. Consumers \& Producers, 2693-2701.

Vesanen, J. (2007). What is Personalization? A Conceptual Framework. European Journal of Marketing, 41(5/6), 409418. http://dx.doi.org/10.1108/03090560710737534.

Vesanen, J., \& Raulas, M. (2006). Building Bridges for Personalization: a Process Model for Marketing. Journal of Interactive Marketing, 20/1, 5-20. http://dx.doi.org/10.1002/dir.20052

Wall, E. A., \& Berry, L. L. (2007). The Combined Effects of the Physical Environment and Employee Behavior on Customer Perception of Service Quality. Cornell Hospitality Quaterly, 48(1), 59-69. http://dx.doi.org/10.1177/001 0880406297246

Walter, A., Mueler, T. A., \& Helfert, G. (2000). The Impact of Satisfaction, Trust, and Relationship Value on Commitment: Theoretical Considerations and Empirical Results. In IMP Conference Proceedings

Wang, Y., \& Kobsa, A. (2013). A PLA-Based Privacy-Enhancing User Modeling Framework and its Evaluation. User Modeling and User-Adapted Interaction, 23(1), 41-82. http://dx.doi.org/10.1007/s11257-011-9114-8

Yoo, J., \& Minjung, P. (2016). The Effects of E-Mass Customization on Consumer Perceived Value, Satisfaction, and Loyalty Toward Luxury Brands. Journal of Business Research, 69, 5775-5784. http://dx.doi.org/10.1016/j. jbusres.2016.04.174

The article has been reviewed.

Received in February, 2016; accepted in October, 2016. 